\title{
The political economy of social protection in Mozambique
}

\author{
Buur, Lars; Salimo, Padil
}

\section{Publication date:}

2018

\section{Document Version}

Publisher's PDF, also known as Version of record

\section{Citation for published version (APA):}

Buur, L., \& Salimo, P. (2018). The political economy of social protection in Mozambique. (pp. 1-34). University of Manchester.

\section{General rights}

Copyright and moral rights for the publications made accessible in the public portal are retained by the authors and/or other copyright owners and it is a condition of accessing publications that users recognise and abide by the legal requirements associated with these rights.

- Users may download and print one copy of any publication from the public portal for the purpose of private study or research. - You may not further distribute the material or use it for any profit-making activity or commercial gain.

- You may freely distribute the URL identifying the publication in the public portal.

\section{Take down policy}

If you believe that this document breaches copyright please contact rucforsk@kb.dk providing details, and we will remove access to the work immediately and investigate your claim. 
The political economy of social protection in Mozambique

Lars Buur ${ }^{1}$

Padil Salimo ${ }^{2}$

August, 2018

${ }^{1}$ Roskilde University

Email: Ibuur@ruc.dk

${ }^{2}$ Roskilde University, University of Dar es Salaam and University of Eduardo Mondlane

Email: Padil.salimo@gmail.com

ISBN: 978-1-912593-04-0 


\begin{abstract}
In the view of international donors, multilateral organisations and government officials, social protection in Mozambique benefits from strong government commitment to it. Their argument is that, in contrast to many African countries, the government has demonstrated a level of commitment and support to social protection that is quite unprecedented. This view relies on the fact that more than 90 per cent of the budget allocated to the implementation of social protection programmes comes from the state budget and that, even within the complex context of the financial crisis that has devastated the economy since 2013 , social protection has continued to receive special attention from the government in its budget allocations. Based on a political economy analysis, this paper challenges the common narrative of social protection in Mozambique, by arguing that social protection has been used as a means to mobilise resources from international agencies, in order to ensure the political survival of the Frelimo government. The paper argues that government support of social protection emerged as a reaction to the poor performance of poverty-reduction initiatives, becoming also a mechanism to overcome social protests after the 2008 and 2010 riots in Mozambique, which threatened to jeopardise the stability of the regime and its reproduction of power.
\end{abstract}

Keywords: Social protection, social transfers, political settlement, ruling elite, patronage, Mozambique,

Buur, Lars and Salimo, Padil (2018), The political economy of social protection in Mozambique. ESID Working Paper No.xx Manchester, UK: The University of Manchester. Available at www.effective-states.org

This document is an output from a project funded by UK Aid from the UK government for the benefit of developing countries. However, the views expressed and information contained in it are not necessarily those of, or endorsed by the UK government, which can accept no responsibility for such views or information or for any reliance placed on them. 


\section{Introduction}

Many donors have hailed the adoption of social protection in Mozambique as a major success because more than 90 percent of its funding comes from the state budget: 94 percent in 2015 (the remaining 6 percent coming from donors) and 96 percent by 2016. Even through these amounts are contested, the fact that the Frelimo government is ready to finance social transfers is seen as a sign of high-level government support. This paper analyses the political economy dynamics underlying implementation of social protection in Mozambique by focusing on two subcomponents: the Basic Social Subsidy Programme (PSSB) and Productive Social Action Programme (PASP).

In 2007, Mozambique's Council of Ministers approved a Law on Social Protection. Almost a decade later, in February 2016, a National Strategy for Basic Social Security (NSBSS II 2016-2024) was approved. ${ }^{1}$ The NSBSS II Strategy comprises four components: reinforcement of consumption, autonomy and resilience; improved nutrition and access to health and education services; prevention of and response to social risks; and a capacity-building component. These programmes had gradually but thoroughly expanded social protection, from an initial 250,000 beneficiary households in 2008 to almost 500,000 by 2016 . The expansion was secured through four programmes: the Basic Social Subsidy Programme (PSSB); Productive Social Action Programme (PASP); Direct Social Support Programme (PASD); and Social Work Social Services Programme (PSSAS) - the first two having the most impact on basic social protection, due to their funding and number of beneficiaries. By 2015, social protection programmes covered roughly 9 percent of the Mozambican population and about 20 percent of those living below the national poverty line. Compared to other African countries, the disbursement is still relatively low, at less than 1 percent of the GDP. ${ }^{2}$

The present economic and political crisis in Mozambique (see Macuane et al. 2017) provides a litmus test for government support. Secret foreign debt revealed during 2016 has seen the IMF and major donors suspend financial aid for most of 2016 and 2017-18, putting massive pressure on the state budget, which for most ministries has meant downsizing by up to 40 percent in a year and leading the government to declare itself bankrupt in November 2016 because of its inability to service the secret loans. Massive internal loans to replace the financial aid that was suspended is putting further pressure on the national economy, now on the brink of collapse, despite large-scale natural resource and energy investments which will only mature at the beginning of 2030. In 2016, the year of research for this paper, the question in the sector was: will the government consisting of different factions continue funding

\footnotetext{
${ }^{1}$ See República de Moçambique (2016). This strategy lays the foundations for a social protection programme in Mozambique that was developed with donor support to expand the first NSBSS I (2010-2014), which was approved in 2010 (República de Moçambique [2010]; see also Boletim da República (2011).

${ }^{2}$ See Marques (2012) and Cunha et al. (2013) both demonstrated that expenditure on social protection in Mozambique is relatively low when compared to other sub-Saharan African countries, where the avarage is around 3 percent of GDP.
} 
social protection in a situation where it is undermining its own ability to reproduce the power it has held since the civil war of the $1980 s ?^{3}$ Recently there has been a further strengthening of donor involvement in the sector, with the government committing resources to PSSB without financial aid and the World Bank continuing to provide loans. The trends depicted in this paper all point in that direction, as social protection has become a safe place for donors interested in poverty reduction to continue aid disbursement while financial aid in the form of direct budget support was suspended.

The starting point for this paper is Khan's (2010) political settlement theory, which focuses on the distribution of power in society between contending ruling elite and non-elite factions, which in turn underpins specific configurations of formal and informal institutions. Khan's framework uses three basic levels of analysis: the vertical distribution of power (within a political settlement); the horizontal distribution of power (between included and excluded factions and groups); and the financing of a given political settlement. Lavers and Hickey $(2015$; 2016) adapt and extend Khan's work. First, Khan (2010) argues that a relatively stable political settlement requires compatibility between ruling elites' power and the distribution of resources resulting from particular institutional configurations. This aspect is related to how a political settlement is financed, which this is extended by incorporating the concept of a distributional regime (Seekings and Nattrass 2005). In our adaption of these suggestions here, a particular distributional regime can include social protection as one mechanism of resource mobilisation (for example, mobilising aid) and distribution (which can be universal or partisan in focusing on distribution to lower-level factions). In this way, social protection can work in tandem with an overall development strategy, social service provision and tax policies. One consequence is that social protection policy is not seen as formulated in isolation from other policies, since it is either part of or a response to specific political and financial challenges affecting the overall distributional regime in Mozambique.

Secondly, Lavers and Hickey suggest (2016) that an analysis of the political settlement can be complemented with one of policy domains, not usually Khan's explicit focus. The concentration on social protection in Mozambique is of particular interest here because, as a specific policy domain, it was not initially at the heart of the policy concerns of the government or all donors. Two developments nonetheless challenged this. First, a crisis in the poverty-reduction strategy saw donors looking for new ways of reaching out to the "poorest and most vulnerable parts of the population'. ${ }^{4}$ Secondly, Mozambique experienced urban riots in 2008 and 2010 that required new ways of 'taming' and including key urban groups, particularly the young. Including a focus on specific policies meets Lavers and Hickey's (2016) suggestion that 'different policy domains are of greater or lesser importance to the political settlement and have their own particular political dynamics' (Lavers and Hickey 2016: 2). This requires that specific policy coalitions related to social protection need to be

\footnotetext{
${ }^{3}$ The research for this paper took place from September to December 2016, at the height of the Mozambican debt crisis.

${ }^{4}$ Even though we in this paper only quote the interview with the Irish delegation, this was shared by all bilateral donors.
} 
expanded from the domestic context to include transnational actors and that their activities be coordinated to advocate policy change, despite diversity in actor interests.

Finally, Lavers and Hickey's (2016) framework focuses on the interaction between ideas and interests, an aspect less developed in Khan's (2010) predominantly interest-based analysis. Understanding how political settlements are organised and legitimised therefore requires that analysing the distribution of power between contending factions includes the ideas, shared and contested, underpinning a particular settlement, as structural constraints and the balance of power between contending factions 'rarely, if ever, determine(s) particular policy responses' (Lavers 2016: 2). Decision-makers at different social levels always have a degree of policy space where specific ideas can be significant and can influence the policies adopted. In analysing the role of ideas in policy-making, Lavers and Hickey (2016) distinguish between three types: policy ideas providing potential solutions to pre-defined social problems; problem definitions providing ways of framing particular social issues, favouring certain types of policy solution over others; and paradigms serving as overarching road-maps. In this paper, we focus specifically on policy ideas and problem definitions related, for example, to poverty reduction and outreach to the most vulnerable parts of society. We argue that they are important in the formation of transnational policy coalitions related to the two policies we analyse. Paradigmatic or foundational ideas related to 'national unity', we argue, operate at a different level of analysis. Ideas like national unity take on a particular feature in former one-party states that have managed to reproduce power, as they can inform how patronage and clientelism are organised. This has particular consequences for social protection and attempts at reforming the implementation of social protection modalities.

The paper employs a process-tracing methodology (George and Bennett 2004) to reconstruct the policy-making process based on semi-structured interviews with senior technical staff within government (nine interviews), representatives of donors and international organisations (11 interviews), domestic and foreign consultants (two interviews), and civil-society and NGO representatives (two), all involved in design and programme administration. ${ }^{5}$ The aim of the analysis is to link this policy-making process to the political settlement and distributional regime that underpin the policy context of social transfers, by drawing on the existing academic literature on Mozambican politics, official policy documents and statistics.

The paper finds that the ruling elite's commitment to social protection, including these two policies, has been shaped by the characteristics of the political settlement and the key challenges confronting the ruling elite. Social protection policies, particularly the PSSB as it evolved in Mozambique, became, we argue, entangled within key distributional problems related to the crisis in poverty reduction. In the case of the PASP, we argue that its adoption by government can be seen as a direct response to

\footnotetext{
${ }^{5}$ With some exceptions, we have anonymised most of our respondents. .
} 
the urban riots of 2008 and 2010 . Frelimo saw both crises as posing a threat to the reproduction of power and thereby the political settlement.

We therefore argue that the objectives and framing of social protection have shifted over time because of these new political challenges. In contrast to other countries (see Lavers [2016] on Rwanda), the Frelimo government viewed social protection predominantly as a social transfer programme, but over time also as integral to addressing key government challenges. Other countries tend not to see social protection as integral to wider government development strategies, which may exist only nominally. This does not mean that government agencies have not actively sought to learn from outside expertise in the international donor community, allowing for the diffusion and anchoring of contested ideas of social protection promoted by development partners. However, in Mozambique these transnational ideas were actively reinterpreted and adapted to assist the government and its agencies to deal with the challenges of political survival.

The paper begins by analysing Mozambique's political settlement and the broader distributional regime within which social protection developed. We focus on the three most recent phases of the political settlement: the Chissano and Guebuza eras, when social transfer policies emerged as a priority; and the present Nyusi presidency from 2015, which has already experienced a major political and economic crisis, reducing the state's ability to distribute resources through patronage. The analysis then turns to the PSSB and PASP, two social protection policies, focusing on the key policy ideas and problems they addressed and the paradigmatic ideas they interacted with. The conclusion summarises our findings.

\section{The Mozambican political settlement ${ }^{6}$}

Mozambique's current political settlement can be traced back to the General Peace Accord (GPA) of 1992, which ended a devastating 16-year civil war between the governing party, Frelimo, and its old foe, Renamo. After the GPA in 1992, Frelimo consolidated its control over the state and economy during the first multiparty democratic reign of Joaquim Chissano's (1994-2004) and became a vulnerable authoritarian coalition, ${ }^{7}$ as the coalition was fragmented, with rudimentary control over lower-level factions and considerable electoral success on the part of the opposition. It strangled and excluded political factions by cutting off access to resources and generally undermined any opposition, which gradually resulted in the (re)emergence of a strong dominant party coalition towards mid-2000, albeit characterised less by elite cohesion than by centralisation of power in the hands of President Amando Emilio Guebuza, who took over as president of the party in 2003 and as president of Mozambique in 2005.

\footnotetext{
${ }^{6}$ This section relies heavily on Weimer et al. (2012); Whitfield et al. (2015); and Macuane et al. (2017).

${ }^{7}$ For the different regime types, we rely in general on Khan (2010).
} 
Guebuza's building of a strong dominant party coalition from the mid-2000s was chiefly based on reasserting a high degree of cohesion within the ruling coalition. The attempt at establishing a broader coalition under Chissano after the GPA had weakened party control over the state, as he gave more power to the technocrats (Macuane 2012). Guebuza first revitalised the party cells from the grassroots up to the highest levels of the state and parastatal companies, including independent or semi-independent units like universities and legal training institutions. This basically maintained a high degree of exclusion of any people considered to be in opposition to the dominance of the Frelimo party. The idea of party membership as a condition for access to public office and state jobs was promoted at all levels of discourse and practice. With regard to the vertical dimension of the political settlement, Guebuza, in contrast to Chissano, sought to consolidate his direct power through a controlled distribution of rents to people loyal to the party, but over time, more importantly, loyal to Guebuza himself.

In other words, Guebuza based the building of a strong dominant party coalition on restoring the politics of Frelimo being the commander of the country and the embodiment of unity where power within the ruling coalition is principally legitimised through a discourse that stresses 'national unity'. In the next section, we briefly unpack the paradigmatic idea of 'national unity', as it informs our subsequent analysis of social protection and more recent attempts to change distribution patterns. One of the most important aspects, if not the most decisive and foundational idea, of Mozambique's political economy has been and continues to be the kind of 'national unity' (Hodges and Tibana 2005) that the Frelimo party embodies (de Brito 2016). The Frelimo party has been in power since independence in 1975 and has changed from its position as the Marxist-Leninist vanguard of a one-party state - proclaimed in 1977, but repudiated in 1990 - to become the dominant party ever since the liberal multiparty constitution of the latter year. In the party's and ruling elites' own understanding, Frelimo is the shaper, even the dono do país (owner of Mozambique's contemporary history) (Weimer et al. 2012). In Frelimo's understanding, the party was first of all a vanguard party with a few men at its helm guiding the masses and using the state as their instrument (Frelimo 1978: 34). Initially, and until well into the 1980s, when Frelimo broadened its membership base, the 'admission of members' was a strict process where only the selected few, those who were considered trustworthy or pessoas de confiança, were admitted to it (ibid. 39). Later, after 2005, this was reasserted under Guebuza, who realigned state institutions with the party after a period of relaxation under Chissano.

While allegiance (and even membership) of the party is still expected today if one wants to work in the state sector or engage in the economy, the 1977 Third Congress made it clear that 'the Party and the State are two distinct entities' (Frelimo 1978: 42). The party was considered absolute or sublime, as it was 'the highest form of political organisation', with the 'Popular State [being] the main profane instrument for putting 
the Party's policy into practice. ${ }^{8}$ The exercise of democracy in this understanding is not solely a matter of 'holding elections and discussing problems'; it is also aimed at 'the struggle for unity' (Frelimo 1978: 36) in a context in which all organisations and individuals outside the party are seen as sources of 'disunity'. Following Hodges and Tibana (2005) we argue that this understanding of 'national unity' has zealously been guarded and is still a principal preoccupation today. All policies - whether social protection, poverty reduction, decentralisation or economic development - are measured against whether they support or undermine 'national unity'. ${ }^{9}$ Within this understanding of legitimate power, the horizontal distribution of resources and opportunities to opposition factions and their vertical distribution within the ruling Frelimo coalition are zealously guarded and in the end become implicitly, if not explicitly, vetted in respect of the project of achieving national unity, in and through the Frelimo party. While cracks in the party's unity have always been evident, despite claims to the contrary, they have recently become glaringly apparent during the recent debt crisis in the gaze of economic transition to a resource-based economy.

\section{The 'Silent Deal': The PSSB's links to the political settlement}

There is a consensus among all stakeholders that the emergence of an international policy alliance promoting social protection in Mozambique came from the international donor community, led by the $\mathrm{UN}$. $^{10}$ The promotion of social protection by the UN and international donors allowed Mozambican state officials and later parliamentarians to participate in international social protection learning and the sharing of experiences with exchange visits to other countries. In 2007 and 2009 the government approved the social protection legal framework, which kicked off social protection with the 'compromise', as one actor framed it, of international aid donors agreeing to provide financial resources to support the Programa Subsidio de Alimentos (PSA) (chiefly DFID and the Netherlands) and assist in developing the institutional capacity (UNICEF and ILO) in exchange for the government implementing the social protection agenda in the long term. ${ }^{11}$

This happened during the first years of the Guebuza regime, but also drawing on the technocratic turn that the Chissano regime embarked on from 1994 to 2004 . Key to the successful promotion of social protection was tapping into a policy space that had opened up related to programmatic aid and poverty reduction through the elaborate

\footnotetext{
${ }^{8}$ While this was the ideological position, the vanguard party and its political leadership did not really trust the state's personnel, partly because many of those who became state functionaries came from the more educated sections of the population that emerged after 1960, when the Portuguese regime began to use more resources to train an African bourgeoisie.

${ }^{9}$ As Alberto Joaquim Chipande, a former general from Cabo Delgado province and a member of Frelimo's innermost cabal, recently stated publicly: 'Frelimo plans to rule for the next 50 years'. In other words, no matter what the will of the people, Mozambicans will have to forget about those in power changing. http://dirayetu.blogspot.com/2015_01_01_archive.html, accessed November 21, 2016.

${ }^{10}$ See UN Mozambique 2015; interview Elsa Alfai, Senior Social Policy Advisor to the Minister of Women and Social Action (MMAS) 21 November 2016.

${ }^{11}$ A Memorandum of Understanding was signed between MGCAS, INAS and donors in 2008.
} 
working group system of the G1912 and its policy dialogues with the government. Social protection thus became part of the yearly decision on targets for results-based aid in 2007, when it was included in the government's and donors' joint monitoring framework for general budgetary support (GBS), followed by its inclusion in the FiveYear Government Programme (PQG) and Poverty Reduction Strategy (PSRP 20102014) in 2010 (Hodges and Pellerano 2010). An informal working group was also set up in 2008 to link social protection to the increasing flows of funding directly allocated to social protection programmes, which was moved from the state budget support mechanism to increased donor co-financing as part of the long-term commitment from DFID and the Netherlands (Hodges and Pellerano 2010). In 2009, the donors' direct budget allocated to INAS, the public agency managing the basic social protection programmes, was almost 20 percent of the state budget. ${ }^{13}$ The figure below shows the decline in direct donor aid to social protection compared to the state budget.

Figure 1. Direct financial support to INAS for social protection programmes ${ }^{14}$

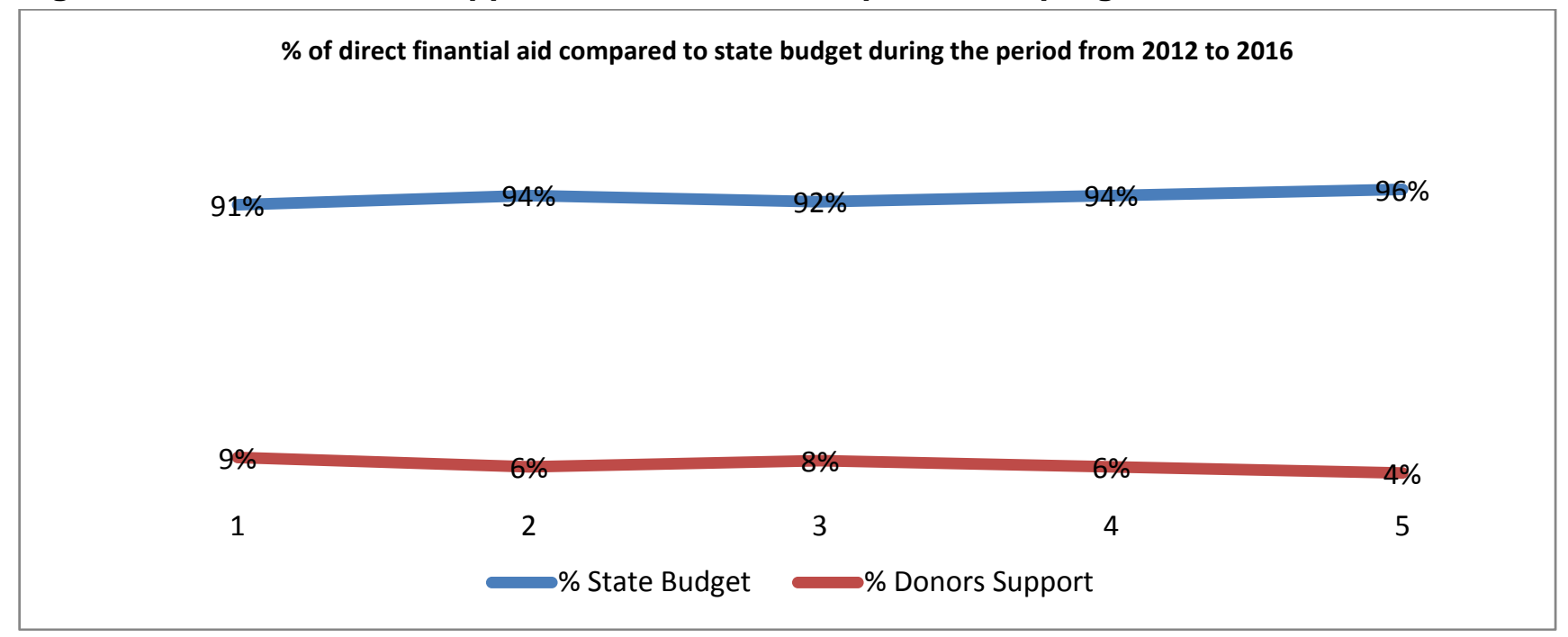

Source: INAS (2012; 2013; 2014; 2015; 2016).

Despite these uncertainties, Figure 1 nonetheless suggests that a strong commitment from the government remained in place, the key being to understand

\footnotetext{
${ }^{12}$ The group of donors known as PAPs (Parceiros de Apoio Programático - Programmatic Support Partners), which provides aid to Mozambique through General Budget Support.

${ }^{13}$ Donors and UN agencies are split on how to support social protection. Traditional bilateral donors emphasise that the unpredictability of donor aid support is not compatible with financing entitlement programmes, the requisite effort being made by the government through allocations from the state budget. Many bilateral donors' efforts thus focus on capacitybuilding and the establishment of adequate systems to allow the government to implement its social protection programmes efficiently, responsibility for allocating the budget for cash transfers being left to the government. Other donors and partners reliant on funding from traditional donors are more pragmatic, especially the multilateral donors.

${ }^{14}$ Figure 1 only counts direct contributions by DFID, Holland and possibly the PASP World Bank loan, despite different views on whether the chart counts the World Bank loan as a domestic or external resource. It definitely leaves out the UN's several million dollar programme in this period, financed mainly by Sweden and Ireland, with some UNICEF and DFID resources. We thank Benjamin Zeitlyn from DFID for clarifying this for us.
} 
why. Interestingly, the figure was used by government, multilateral and bilateral actors to support the expansion of social transfer in Mozambique, being taken as a bone fide sign that the government was behind the shift in social transfer thinking and had taken ownership of the process. It is clear from our interviews and meetings that many of the different donor representatives have worked on social protection in similar countries, in which the financing was typically externally financed and in many instances run by external agencies. In contrast to donor representatives' experiences in other countries, as Figure 1 suggests, the system in Mozambique is still largely financed domestically. ${ }^{15}$

Even with all the signs pointing in the direction of a different political economy history of social transfers in Mozambique, one key actor described it as a 'silent agreement' developed between donors and the government regarding social protection. We will return to what the 'silent deal' means in more detail. In essence, here, it referred to broader donor-government aid relations, whereby the government's payment of 94percent of social transfers in exchange for support in building up the social transfer system was based on the donors also paying a huge percentage of the state budget through different kinds of budget support and loans. We discussed the issue of a 'secret agreement' with all the agencies we interview here with state functionaries working with social protection, and they all confirmed that in reality the state commitment was premediated by donor promotion as well as direct and indirect funding.

\subsection{The silent agreement}

In different ways, all members of the international donor group reiterated what one of our UN interlocutors argued directly:

'We are so proud of the government because they have kept to their financial commitments and continued to support the sector even during the crisis with disbursements. It makes a big difference [...] What has been beautiful is that a new strategy has been approved with a model set-up that is mind-boggling, that is complex, that can engage with poverty, that is preventive of (social) risks and can mitigate climate change, approved at the highest levels'. ${ }^{16}$

But the government ownership was, as one donor representative suggested anonymously (and confirmed by various donor representatives, as well as state functionaries working with social protection): '... based on the silent deal that the government provides the money for transfers and the development partners and the UN-UNICEF build the system', thus allowing the 'system to be linked to outreach'. ${ }^{17}$

\footnotetext{
${ }^{15}$ This is the case, even if we include the UN and World Bank programmes, as external finance that is not included in Figure 1.

${ }^{16}$ Interview, UN agency, 25 October 2016.

17 Interview, multilateral aid partner, November 2016.
} 
We will suggest this 'silence' related to donors then funding a large part of the state budget. ${ }^{18}$ As such, it is part of how donor-government relations are organised in Mozambique, approximating to what Renzio and Hanlon (2008) have called more generally: a 'pathological equilibrium' between donors and government. For the social protection sector, this entailed an acknowledgement that the government's 94 percent payment of transfers in exchange for capacity-building was based on the fact that the donors were also paying for a huge percentage of the state budget. ${ }^{19}$ External aid funding the state budget has severely declined after the debt crisis hit government spending seriously in 2016 after the IMF had suspended its programme in Mozambique due to concerns over transparency, with the consequence that General Budget Support and financial aid have been suspended (see Macuane et al. 2017).

In this sense, the 'silent deal' enabled Mozambique's international development partners to tell a story of successful poverty reduction based on social protection, with strong government ownership to encourage further disbursements of aid by donors and the government's continued support for social protection, making sure that what had been achieved would be sustained.

The 'silent deal' therefore reveals some of the underlying incentives at play around the scaling-up of support for social protection. Furthermore, it allowed the government to pursue a programme that had emerged from the international donor community, but that it increasingly accepted as its own, as if it was its own policy, while at the same time using it for regime survival and patronage, as explored below. It thus supported the quest for 'national unity' organised in and around the Frelimo government.

Importantly, therefore, we are not arguing that government support was just a 'mirage' and that government 'ownership' in Mozambique is just a donor-driven system. Rather, we need to explore how and why the government came to support social transfers just as more donors became involved. We will suggest in particular that the 'silent deal' is underpinned by the broader policy discussion related to the crisis of poverty reduction (the PRSP) and the urban riots of 2008 and 2010 that came to dominate government-aid donor relations from 2008 onwards. The poverty crisis in particular threatened to take resources away from the government exactly when donors needed to show positive results related to increased support. Here social protection and the long-term strategic work of some of the donor groups, like the DFID and the Dutch, came in handy for a broader group of donor missions, as a more concrete and targeted approach to the task of reaching 'the poorest of the poor', in contrast to the PRSP's focus on broadening access to basic social services. Furthermore, as the main social protection programme, the PSSB also tacitly suited the distributional logic guiding the organisation of power of the ruling Frelimo

\footnotetext{
${ }^{18}$ This 'silence' is therefore not related to donor financing of building up the bureaucracy in charge of social transfers so that the government could accept increasing 'domestic' financing, as this was an explicit strategy.

${ }^{19}$ Interview with senior official at multilateral aid partner, November 2016.
} 
coalition. In this way, the PSSB fitted into the broader processes in the evolution of the political settlement under the Guebuza regime. The next sections will briefly explore what the PSSB was concerned with, before exploring its relationship to the poverty crisis and patronage.

\subsection{The PSSB}

The Basic Social Subsidy Programme (PSSB) ${ }^{20}$ is the longest-standing basic social protection programme to emerge to date out of the 1990 Programa Subsidio de Alimentos (PSA), ${ }^{21}$ the objective of which was to assist the 'destitute elderly, people living with a disability, the chronically sick and their dependants through the provision of a monthly cash transfer' (Soares et al. 2009: 2). Over time, the PSA became the main social protection programme in Mozambique, with cash transfers to the poor and vulnerable, in general covering: (i) the elderly, i.e. aged 55 (women) or 60 (men) or over who had been unemployed for two years or more; (ii) chronically disabled people over 18 years old; and (iii) families with undernourished pregnant women (Massingarela and Nhate 2006; Mausse and Cunha n.d.). Initially the PSA was established to focus on poor families in urban areas who had been victims of the civil war. The World Bank had been a key actor influencing the adoption of the PSA as a mechanism to redress the social costs of structural adjustment in the 1990s (Massingarela and Nhate 2006), ${ }^{22}$ but it had nothing to do with the later version of the PSSB.

In 2008, at the height of discussions over poverty reduction in Mozambique, the Ministry of Woman and Social Affairs (MMAS), the Ministry of Planning and Development (MPD), the Ministry of Finance (MF), the Dutch Embassy (EKN) and DFID signed a Memorandum of Understanding (MoU) to establish the basis for financial support of the PSA cash-transfer programme. With the approval of the Regulation of Social Protection Law and the Strategy for Basic Social Protection, the PSA was reviewed and replaced by the PSSB under Decree No. 52/2011, which established the Basic Social Protection programme. The PSSB was conceived as a long-term cash-transfer programme targeting extremely poor households with no adult able to work, without the means to satisfy their basic needs, and headed by the elderly, those with disabilities, or people with chronic or degenerative diseases (for a critic of the social protection focus used by the Mozambican government and donors, see Francisco et al. 2011; Francisco and Sugahara 2015).

The PSSB is the largest programme for basic social protection in Mozambique, covering 79 percent of all the beneficiaries of basic social protection in 2016 and

\footnotetext{
${ }^{20}$ Under Decree no. 52/2011, the government created four programmes for basic social protection: (i) Basic Social Subsidy Programme (PSSB); (ii) Direct Social Support Programme (PASD); (iii), Social Services of Social Action Programme (PSSAS); and (iv) Productive Social Action Programme (PASP).

${ }^{21}$ Food Subsidy Programme.

22 The mandate to implement the PSA then fell to the GAPVU, a unit within the Ministry of Finance that was later transferred to the Secretariat of State for Social Action (SEAS). The latter institution was subordinated to the Ministry of Health, which over time became INAS.
} 
reaching a total of 370,291 households. More than 60 percent of the total budget for basic social protection system is channelled to PSSB (INAS 2016).

Figure 2. Budget allocated for basic social protection programmes per year as percentage of GDP

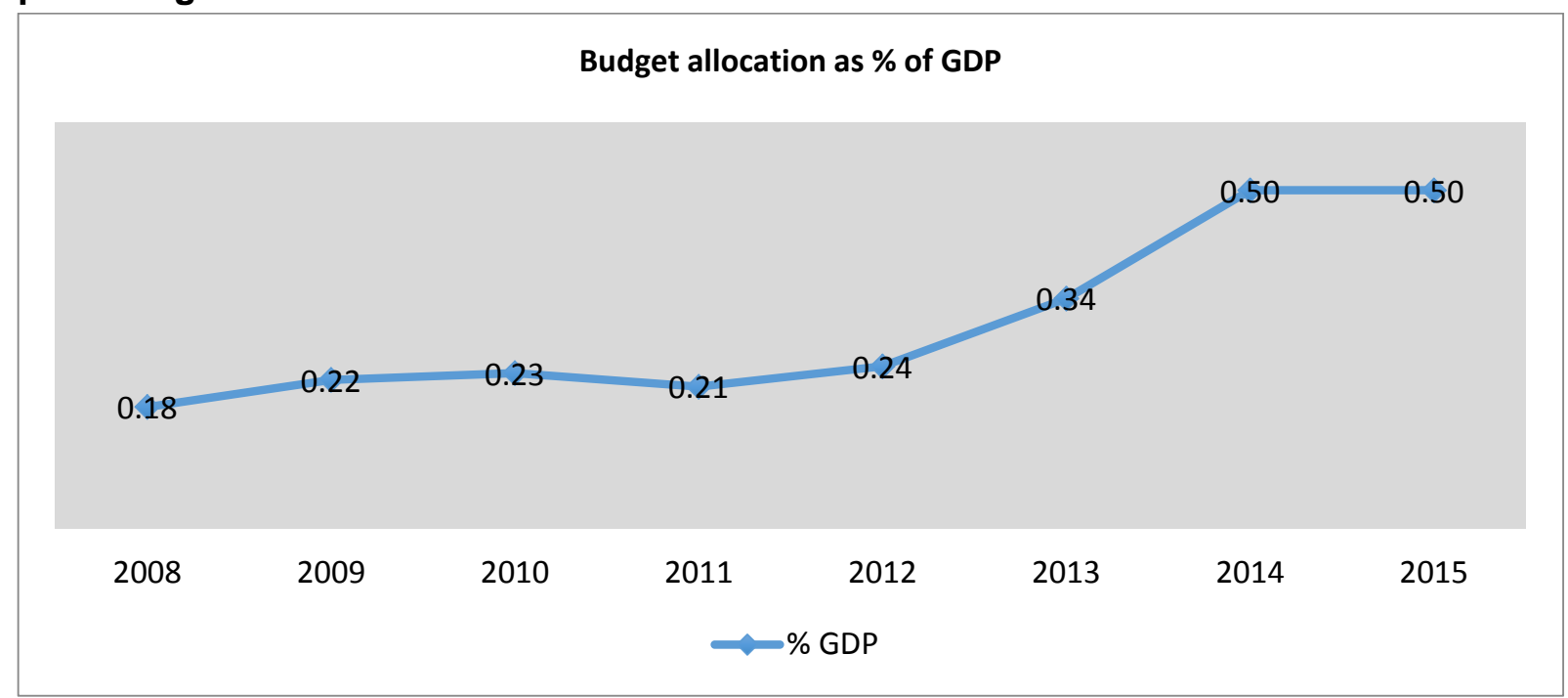

Source: ILO and IMF (2012); UN Mozambique (2015); Barnes et al. (2016); INAS 2015.

The budgetary allocations nearly tripled over six years, indicating the increased attention being given to social protection in Mozambique by the government and international donors. Despite the significant increase in the budgetary allocation for 2008-15, the related percentage of GDP is still under the 0.8percent the government plans to be achieved in 2014 to 2016 for social protection floors (ILO and IMF 2012; Cunha et. al. 2013). In the next section, we briefly consider the political economy underpinnings of these changes, the key to understanding which is the poverty reduction crisis.

\subsection{Social transfers as the new poverty frontier}

Before the poverty reduction crisis, the social protection sector was on the cusp of the PRSP process, with its programmatic focus on poverty reduction. After the crisis, the social protection emerged as a key sector in progressively addressing the goal of 'reaching the poorest of the poor and most vulnerable', ${ }^{23}$ which, after all, is what legitimised increased aid distributions. ${ }^{24}$ One of two 'turning points' in this situation was the poverty-reduction crisis that hit Mozambique in 2008-09.

National data on Mozambique's PRSP suggested that the first PRSP 'enjoyed considerable success' (Waterhouse and Lauriciano 2009: 6). Data from the First

\footnotetext{
${ }^{23}$ Interview, November, Irish delegation.

${ }^{24}$ Interviews with programme donors, Maputo, October-November 2016.
} 
National Poverty Assessment (IOF) ${ }^{25}$ collected in 1996-97, in contrast to data from the Second National Poverty Assessment collected in 2002-03 (MPF 2004; Buur and Baloi 2009), showed impressive gains in the 'fight against absolute poverty', as President Guebuza expressed it. According to the IOFs, the number of those in absolute poverty, defined as those living on less than US $\$ 1$ per day, ${ }^{26}$ fell from 69 percent of the population in 1997 to 54 percent in 2003. Furthermore, even though income inequalities increased (Mozambique News Bulletin 344, 2016), the data suggested that, given the very high and consistent levels of economic growth, combined with the strong poverty-reduction focus, broad-based poverty reductions targeting the poorest sectors of society did indeed occur. The apparent success of the first PRSP was what all donors relied on in engaging in the new poverty agenda and focus on national ownership, with budgetary support being organised around the UN's Millennium Goals. The results of the third National Poverty Assessment collected in 2008-09 were therefore greatly anticipated, and President Guebuza stated that he expected 'absolute poverty' to be well under 50 percent in 2008, as a sign of the success of his presidency and the Frelimo government's policies. ${ }^{27}$ But things did not go as planned, and the government delayed releasing the third National Poverty Assessment (IOF) data in 2008. Donor missions close to the Ministry of Planning and Development (MPD), where the research department (DNEAP) was in charge of extracting information from the IOF, had been told informally that there were 'problems' with the data, as the results were less positive than expected. ${ }^{28}$ The data therefore needed to be 'cleaned' further, and its official release was postponed until further notice, not to be released before 2010 .

Even though economic growth had been impressive in 1996-2002, when the economy grew by a cumulative 62 percent, according to official statistics, and growth had continually been at around 8 percent (World Bank 2016), it did not seem to be having the desired effect on poverty reduction. ${ }^{29} \mathrm{~A}$ heated public debate materialised between UN agencies, Mozambican NGOs, international donors and different international and national research consortiums that either backed or challenged the PRSP's focus on social sectors and the government's economic policy (see Mozambique News Bulletin 2016. Special report on the four poverty surveys).

For President Guebuza in the lead-up to the 2009 national elections, when he was again the Frelimo candidate, there was no doubt: 'Those who say that poverty has

\footnotetext{
${ }^{25}$ The first two family expenditure surveys were called IAF (Inquérito aos Agregados Familiares) and the most recent ones IOF (Inquérito sobre Orçamento Familiar). We use IOF here for both types of survey.

${ }^{26}$ In reality a figure closer to $\$ 0.82$ was that actually adopted in Mozambique.

${ }^{27}$ Personal notes 2008.

${ }^{28}$ The DNEAP (National Directorate of Studies and Policy Analysis) is formally funded by the government through a huge capacity-building component receiving funding from a range of embassies, among them the Danish Embassy. Capacity-building is organised through Copenhagen University's Institute for Economics.

${ }^{29}$ It should be noted that the impressive growth figures and calculations of growth started from an extremely low level before the GPA and with a severely depleted economic base following the war years.
} 
not declined in Mozambique suffer from "a deficit of information" that does not allow them to have a full view of what has been done over the past 16 years of peace and reconstruction' (President Armando Guebuza, August 22, 2008, quoted in the Mozambique News Bulletin, 2008). The official reasoning was that:

'the expansion in the education and health services, in the national electricity grid, and in the fixed and mobile telecommunications networks, clearly showed that the Mozambique of today is much better than the Mozambique of yesterday. Previously, we scarcely had any of this, and this is all proof that we are overcoming poverty, that we are improving our lives, that poverty is on the decline' (ibid.).

However, a series of studies were produced showing that poverty reduction was uneven and had hardly reached the poorest sectors of the population (see, for example, Tvedten et al. 2006; the 2008 Multiple Indicator Cluster Survey (INE 2009) supported by UNICEF; see also the later UN (2011) study of Child Poverty and Disparities in Mozambique). ${ }^{30}$ Studies increasingly began suggesting that the 'poorest of the poor' were not covered by the usual PRSP policies. By September 2008, the 'paradox of rising chronic child malnutrition in the face of rapid GDP growth'31 was challenging the view of Mozambican poverty reduction as a success story.

What the alternative studies of poverty began suggesting, in the absence of official data, was that there were problems with the model of poverty reduction and economic growth (Hodges and Pellerano 2010; WFP and INAS 2012; Cunha et, al. 2013; UN Mozambique 2015). It is within this context that social protection became a key answer to the crisis in poverty reduction, as it formally promised to reach the 'poorest of the poorest and most vulnerable segments of society', while at the same time continuing the flow of aid towards the regime. It became an answer that legitimised the continuation of aid disbursements, despite all the indications from the yearly programmatic aid review that the results were not up to standard and that the government had repeatedly broken the underlying conditions of the Programmatic Aid Framework (PAF). Social protection, due to its target and mode of targeting, would be the ultimate 'PRSP policy' field to focus on if the aim was to reach the poor. The emergence of social protection is therefore a good example of how a certain definition of a problem comes to inform that problem when certain policy ideas provide potential solutions to it without, we suggest below, challenging the distributional regime underpinning the political order of which aid was such an important part.

\footnotetext{
${ }^{30}$ The UN (2006) Childhood Poverty Study: A Situation and Trends Analysis, and the UN (2010) Study on Child Poverty and Disparities in Mozambique (United Nations 2011), funded and promoted by UNICEF, argued that nearly 12 million, or 55 percent of the population, were living below the poverty line of around $\$ 0.50$ per day, as poverty-reduction rates have stagnated.

${ }^{31}$ British High Commissioner, quoted in Mozambique News Bulletin (2010).
} 


\subsection{Controlled patronage}

During his presidency, Guebuza sought to consolidate his and Frelimo's power through a controlled distribution of rents in the name of 'national unity'. A good example of this process is the way the so-called seven-million fund, aimed at financing local-level economic projects at the district level, was introduced and implemented. This fund was part of the process of decentralisation initiated during the Chissano era, but it was first implemented during Guebuza's mandate. The allocation of the seven-million fund to district government was an essential part of the patron-client relationships that Guebuza was building up by making sure that the funds mostly benefited Frelimo members and supporters, thereby securing party control over resources and underpinning the quest for 'national unity' organised in and around Frelimo. ${ }^{32}$ Did the Basic Social Protection System break with this distributional logic?

We suggest that the PSSB tacitly follows this distributional trend, as it is based on the selection of beneficiaries by the permanentes (neighbourhood secretaries, community leaders and others (s)elected by the local-level community Frelimo secretaries, or lower-level district officials like traditional leaders who are used by the party-state locally). Organizationally, the implementation of basic social protection programmes, including the PSSB, falls under the responsibility of INAS. INAS uses permanentes from within the local community to assist in identifying programme beneficiaries, to ensure communication between INAS and local communities, and to some extent to assist households in need of help. There are about 5,000 permanentes all over the country. It is generally argued (Hall and Young 1997; Whitfield et al. 2015) that they act like intermediaries between the party and the state, due to the nature of the incentives that exist by virtue of the country's political settlement.

Discussing modes of distribution with members of INAS, MGCAS, the CSO platform, NGO researchers and different donor groups, it was generally accepted that this was not an optimum system, for a variety of reasons. First, it was not a very efficient system, as it required a bureaucracy that could identify, vet and distribute funding at all levels, thus making the system very costly to operate, given the sheer number of beneficiaries. Secondly, it reproduced the vertical dimension of power in society, as it fed into the generalised patronage system described above, whereby it became a tool for rewarding loyalty or encouraging opposition groups to become part of the Frelimo patronage system. Thirdly, it reproduced the horizontal dimensions of the political settlement whereby opposition members and communities are excluded, thus increasing the tensions and divisions in society. With regard to the aspect of exclusion, national distribution patterns suggest that most transfers to local levels of the state are slanted towards provinces in the south and extreme north of the country, historically considered Frelimo-friendly. Except for the extreme north, this is also where we find the lowest numbers of poor.

\footnotetext{
${ }^{32}$ See Forquilha and Orre 2012: 168-96; also Weimer et al. 2012.
} 
Figure 3. Cumulative budget distribution per capita by province: 2008-16

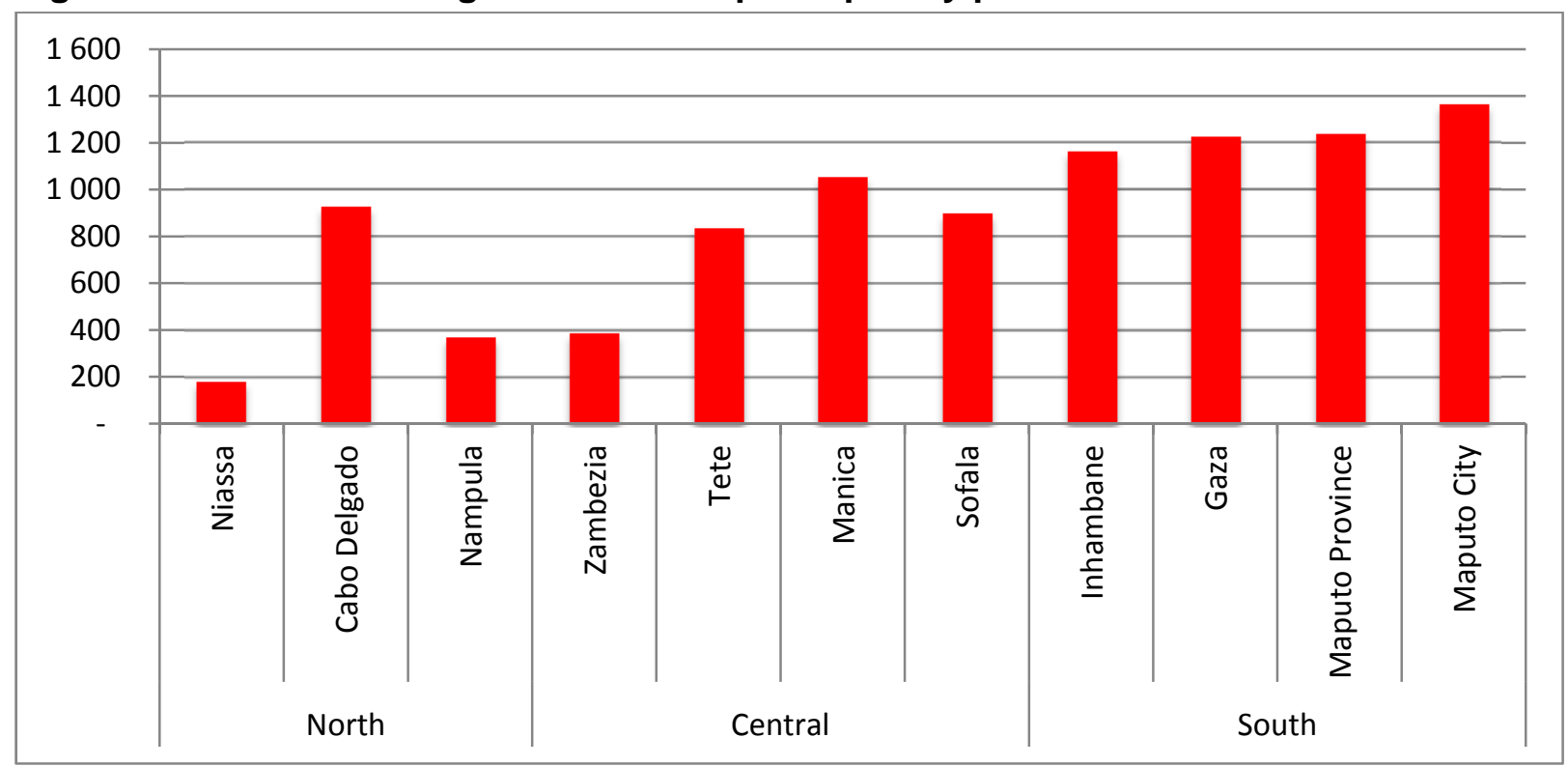

Source: Yearly Budget Law (2008 to 2016) and INE (2007).

For social protection in general, INAS's own information on distributional patterns suggests that the four southern provinces and the extreme northern province of Cabo Delgado, all considered key Frelimo election provinces, receive far more, relatively speaking, in social protection than the central and northern provinces, which are associated politically with the opposition. These are also the provinces where poverty figures consistently show that most poor people reside.

These patterns were confirmed to us when discussing how members of INAS engage with the formal requirements of non-biased selection by following bureaucratic principles in the identification of beneficiaries and the pressures within the system to select beneficiaries based on party membership. For example, in Tete Province, some districts where INAS is assisting poor and vulnerable populations through the PSSB programme have provoked the concern of the Frelimo-appointed provincial governor, who has questioned why PSSB activities were taking place in specific areas of Tete where INAS had implemented the PSSB. Members of INAS (confirmed in interviews during 2016) realised that the problem with the areas where PSSB had been rolled out - based on universal principles - was that the families who were benefiting from social assistance provided by the government through INAS were not considered 'Frelimo-friendly communities'. During a meeting with INAS, the governor claimed that Tete Province did not have any poor or vulnerable populations. In other words, he was trying to express disappointment with the fact that in effect the presence of INAS programmes confirmed the existence of poor and vulnerable populations in the province. INAS representatives realised that the reason for the governor's disappointment - given that he was perfectly aware of the existence of poverty in Tete - was that the districts in which INAS had implemented the PSSB were those of high levels of political conflict between the main political parties, with Renamo enjoying the greater influence. 
In a similar fashion, one donor employee recounted how a group of partners related to the PSSB, who were visiting the district of Lago in Niassa province, were told that the specific regions where the PSSB had been implemented had mostly been selected for the receipt of benefits on a technical basis. In reality, however, one of the key considerations had been the existing level of support for the ruling party. In many cases, regions that were perceived to be pro-opposition were normally left out, to avoid misunderstandings or threats of reprisals from top government and party officials. As such, the PSSB was used to target specific communities and regions, with a bias towards those where Frelimo was in control. This might suggest that these cases reflect variations in how efforts to secure political loyalty are targeted. The Frelimo-controlled state has distributed cash-transfer funds to (less poor) Frelimo areas, as well as targeting some districts where the opposition Renamo party poses a significant threat. These different uses of social transfers clearly exist, as local populations are told by lower-level state and party cadres that state benefits are only for Frelimo party members, or for those that want to become members of the Frelimo party. ${ }^{33}$ At the same time, where it was possible to build loyalty in areas influenced by the opposition, ruling Frelimo officials have scrupulously selected families to benefit from social protection programmes and thus used social protection to build a support base. State officials in particular gave examples of this, but bilateral donors also gave examples of how social protection was used by the government as patronage.

As we have suggested, there have always been cracks in Frelimo's control and quest for national unity. When INAS staff tried to follow bureaucratic and technical rules in order to accommodate donor criticisms, this was obstructed by Frelimo provincial government officials, who considered that it undermined the party's interests. ${ }^{34}$ So, while reaching the poorest and most vulnerable, the programmes also sustained the Frelimo state through 'capacity-building'. ${ }^{35}$ A real focus on the poor, based on universal principles, would have hampered the Frelimo state's ongoing deepening of its 'territorial reach' - a key dimension of the state's capacity - by rolling out social policies in such a way that the party would not benefit from them directly. This would, in other words, challenge the distributional logic embedded in the policy of 'national unity', as it would no longer be possible to issue grants based on patronage, implicitly shattering the equilibrium that had been created between donors and the government. As the next section makes clear, serious attempts are now being made to change at least some of the 'business as usual' habits, with the World Bankfunded PASP project - even though the government's acceptance of it was intimately linked to its own survival.

\footnotetext{
${ }^{33}$ This follows clearly the trajectory that studies published by EISE on decentralisation have elucidated, as well as multilateral and bilateral interviewees' observations from visits to the provinces that were discussed in interviews.

34 In support of this, a recent study financed by the Swedish embassy (ORGUT 2016) in the name of aid 'reality checks' shows that the poorest and the most vulnerable hardly have any connection with state entities (see also Francisco and Sugahara 2014: 281.

${ }^{35}$ Interview, António Francisco, November 2016.
} 


\section{Social protection and regime stabilisation}

The emergence of the Productive Social Action Programme (PASP) emerged and took shape in the aftermath of the 2008 and 2010 riots. A labour-intensive public works intervention that targets extremely poor households which have one or more adults able to work, the PASP provides direct employment in public works projects, or access to employment through training and educational programmes. It is funded through a World Bank $\$ 50$ million loan. According to World Bank representatives, it has tried to break with the 'business as usual' approach characterised by INAS social protection activities involving random identification of the poor and needy, very high transaction costs, and the distributional logic of patronage ${ }^{36}$ Even though we mainly directly quote a World Bank representative, the state representatives whom we interviewed and the donor representatives confirmed the account presented here. The donor representatives often based their views on a critique of the World Bank approach, but also an acknowledgement, by at least the bilateral donors, of the need to try to break with how social protection hitherto had been implemented in Mozambique. But, at the same time, they struggled with accepting what was seen as the 'taking over' of the sector by the Bank, which had previously been critical of social protection.

The PASP, though approved and initiated in 2013 (for a critique of the programme, see Francisco 2013), first really kicked off during the 2016 financial and political crisis, when the Mozambican government ran into financial problems and 'relaxed' attempts to smooth the reform agenda embedded in the PASP. By 2016, the programme was becoming increasingly important, as it would obtain secure funding if the reform agenda was accommodated. The potential to transform the arrangements concerning social protection raised various anxieties among the core donor and UN social protection group about whether the Bank was hijacking the social protection sector.

The emergence of the PASP will first be discussed in relation to the 2008 and 2010 riots. These which coincided with the much-anticipated release of the fourth IOF in 2008-09, more than a year after it should have been released, showing that poverty reduction had indeed stagnated. This led to an unlikely alliance around social transfers, with the government, the IMF, the World Bank, other UN agencies and the programmatic aid donor group agreeing on the provision of a fiscal space for the promotion of social transfers. We will then discuss some of the reasons for the government pursuing the PASP related to social conflicts, based on readings of how such conflicts had been dealt with in South Africa. Then the reform agenda embedded in the PASP and the 2016 socio-economic crisis will be discussed, before taking up some of the criticisms of the PASP.

\footnotetext{
${ }^{36}$ In the Bank's assessment, the PASP was 'the first chance to implement social protection policy in the context of disaster risk management and climate change adaptation on a practical level' (World Bank 2013: 6). This ability to link social protection to 'disaster management' saw a new \$10 million loan approved at the end of 2016, aimed at coordinating the links between different ministries, agencies and social protection programmes.
} 


\subsection{The first and second riots}

Formally, it was the government of Mozambique that 'requested' the World Bank's support for the design and implementation of the PASP in 2012 (World Bank 2013: 7). However, the events that provided the context for the PASP were the poverty crisis discussed above and the riots in 2008, the actual trigger being the later riots that began on 1-3 September 2010. The reason for the significance of the riots in understanding the launch of the PASP was that the government experienced them as an existential threat. As we know from discussions of resource curse effects in Africa and elsewhere (Frynas et al. 2017; Macuane et al. 2017), the interpretation of particular incidents and events can create expectations and shared aspirations that in themselves can have political and economic outcomes. The significant factor is not whether the riots really could have toppled the Frelimo government, but that they were experienced as if they could have done so.

On 5 February 2008, riots broke out in Maputo, spreading first through the southern part of the country before hitting the central region of Manica hard. Under pressure from international donors, in February 2008 the Mozambican government had increased fuel prices, which fed into higher public transport prices. Collectively the chapas that catered for the majority of commuters decided to strike against the rising fuel costs. A few days later, the government reversed its decision and reinstated a new system of fuel subsidies in order to appease the urban populations. For many donors that took the PRSP seriously, this was considered a tipping point, and they began looking for other ways of providing funding for poverty reduction than the general budget and sector support that funded the 'pathological equilibrium' (Renzio and Hanlon 2008) characteristic of government-donor relations.

These were the first serious riots in Mozambique for more than two decades. Not since the 1990 riots, when Mozambique reached the 'riot threshold' during the period of structural adjustment policies (Hanlon 1991: 144), had the regime been challenged by large-scale popular protest outside the controlled and manageable realm of democratic elections (Buur 2015; Bertelsen 2014). These events came to be widely referred to as the 'Food Riots' (Walton and Sneddon 2011).

The 2010 riots also targeted, and in some instances briefly occupied, so-called 'sovereign spaces', as well as attacking suburban public spaces like police stations and schools (Bertelsen 2014). In 2010, public transport again shut down, this time after announcements of rises in import duties on a range of foodstuffs, as well as for fuel and public goods like electricity provided by the state. These announcements again reflected attempts to remove or reduce subsidies under pressure from the international aid community, as the subsidies still benefited urban populations instead of the much poorer rural parts of Mozambique. This suggests that the riots were not necessarily a revolt of the poorest, but more a revolt against the loss of certain privileges (like cheap imported food and fuel). This time, too, text messages featured 
prominently, not just as a way of stirring up protest, but also in the build-up to the riots themselves. ${ }^{37}$ But clearly young people played an important role.

The 2010 riots happened roughly a year after the landslide elections in which the Guebuza regime wiped out nearly all the opposition (see Macuane et al. 2017). The results were a combination of fraud, manipulation and tight control over close to 4 million Frelimo members, who knew that their active participation in the elections would ensure their continued inclusion and access to scarce resources like jobs, promotion and other privileges. While the government initially tried to minimise the importance of the riots, they were nonetheless interpreted as challenging the regime. Sheik Abdul Carimo Sau, the current president of the National Electoral Commission, told President Armando Guebuza that they were 'a popular revolt against the established order' (Noticias, 15 September 2010, quoted in Mozambique News Bulletin 2010). The anti-establishment undercurrent was reframed by the government and donors interpreting the riots as mainly food and bread riots, which allowed the poverty agenda and aid flows to continue. However, the threat to the regime was taken seriously, having an impact on the government and influencing its expenditure. It is in this context that Frelimo also saw new opportunities in social protection. ${ }^{38}$

\subsection{Policy responses}

After the 2010 riots, the government admitted for the first time that poverty is increasing' (Mozambique News Bulletin 2010). Even though the IOF had not yet been released, the results of the 2008-09 survey had been presented. ${ }^{39}$ The poverty survey was submitted to the Council of Ministers in July 2010, but only published by September 2010, making it clear that poverty rates had increased from 54 percent in 2002-03 to 55 percent in 2008-09. Increases in poverty have been particularly dramatic in the centre of the country, in provinces like Zambezia, the most populous and poorest of all provinces, where 'consumption poverty' rose from 68 percent in 1996-97 to 70 percent in 2008-09, after years of government neglect as a 'rebel' province. But Zambezia was not alone in showing higher poverty rates in 2010 than 14 years earlier: the central Manica and Sofala provinces (also considered rebel provinces) showed increased poverty compared to 2002-03. Urban poverty was also rising, with Matola outside Maputo and Nampula all showing increased poverty in 2008-09, despite urban poverty having fallen nationally from 52 percent to 50

\footnotetext{
${ }^{37}$ One message circulating asked: 'Mozambican - prepare yourself for the great day of strike [grève] 01/09/10. We will reclaim the rise in prices, in electricity, water, rice, public transport and bread. Send to other Mozambicans' (Bertelsen 2014: 3-4). However, even though the SMS was discussed on the radio and mentioned in newspapers, nobody seemed to take it seriously. When the riots broke out, it seemed to come as a major shock to the public authorities, as well as to ordinary citizens.

${ }^{38}$ Besides social transfers, a new programme to fight against urban poverty, known as PERPU, was approved to be implemented in the municipalities located in the provincial capitals, following almost the same approach of the so-called 7 million discussed earlier.

${ }_{39}$ This was done by the Ministry of Planning and Development in a presentation in July 2010 and distributed by the Centro de Integridade Publica (CIP).
} 
percent, with Maputo city seeing poverty drop from 54 percent to 36 percent. In contrast, rural poverty increased from 55 percent to 57 percent. ${ }^{40}$

Then a major shift occurred when, in a total change of policy, the IMF urged that Mozambique should establish 'conditional cash transfers to the poor, as was successfully done in countries such as Brazil and Mexico', ${ }^{41}$ to stabilise the situation and support the broad-based poverty-reduction drive through the conventional sectors. The IMF therefore endorsed what was seen as the single most important policy shift by long-term commentators on social policy in Mozambique. ${ }^{42}$ As Hanlon argued at the time:

'there is already a "food subsidy", which is really a small non-contributory pension, which goes to more than 100,000 older people in Mozambique. But the Brazilian and Mexican programmes are very much larger, and this is probably the first time that anyone as important as the IMF has proposed such a large grant. It would probably cost in the range of $0.5 \%$ to $1.5 \%$ of GDP' (Mozambique News Bulletin 2010).

The IMF's new understanding of social protection in relation to Mozambique was directly related to the riots and the rapid growth of the economy. The IMF endorsed this policy in speeches at the time that supported 'the various subsidies and price cuts announced in response to the riots', but it also warned that 'care needs to be taken that measures remain affordable [...] keeping inflation under check is ultimately the most sustainable way to protect real incomes, particularly for the poorest segment of the population' (IMF director Lledo, quoted in Mozambique News Bulletin 2010).

This played directly into the work being done as part of the development of National Basic Social Security Strategy $\left(\mathrm{ENSSB}^{43}\right)$ I by the development partners and UN agencies through the basic Social Protection Working Group, with the ILO promoting the idea of creating sufficient fiscal space ${ }^{44}$ in the state budget to implement social protection measures. But they came up against strong forces. President Guebuza

\footnotetext{
${ }^{40}$ In contrast, the non-monetary poverty data showed that education was improving and that access to health services had improved in rural areas, though strangely deteriorating in urban areas, while access to water saw a big improvement in urban areas, particularly in the south. The last poverty evaluation, IOF (2014/2015) from 51.7 percent in 2008-09 to 46,1 percent in 2014, but significant inequalities remain between regions, with the north showing worsening poverty, from 45.1 percent in 2008-09 to 55.1 percent in 2014-15 (MEF-DEFS 2016). According to experts on poverty surveys in Mozambique, if the surveys had been conducted in 2016 , the figures would be totally different, indicating a very critical poverty situation due to the current economic crisis.

${ }^{41}$ The IMF representative in Maputo, Victor Lledo, speaking to the donor group on 15 September 2010. This was repeated at a presentation at the Bank association the same week in Maputo (personal notes, Millennium Bank, BIM).

${ }^{42}$ Personal discussion with Hanlon, 2016.

${ }^{43}$ From the original name in portuguese, Estratégia Nacional de Segurança Social Básica ENSSB.

${ }^{44}$ By fiscal space, we mean the 'room in a government's budget that allows it to provide resources for a desired purpose without jeopardising the sustainability of its financial position or the stability of the economy' (Heller 2005, cited by Cunha et al 2013: 33).
} 
argued that: The lack of a habit of hard work is perpetuating hunger and poverty. We have to work more and harder. [...] There are many lazybones in Mozambique. We have to admit we don't work much.' He added that these are people who 'relax without having done anything, and then become tired of so much relaxing' (quoted in AIM, 17 April 2007, 'Guebuza insists on the "The Habit of Hard Work"'; see also Mozambique News 2007).

These ideas concerning 'laziness' clearly fit a type of 'problem definition' that provides ways of framing particular social issues in which certain policy solutions come to dominate, even though these ideas concerning laziness predominated over other ideas about how to deal with poverty at this time, as we explore further below. In line with the president's condemnation of 'laziness' and 'poverty', many government officials saw investment in social protection as a waste of resources (UN Mozambique 2015). They were therefore reluctant to consider social protection and cash transfers as key channels for reducing poverty and vulnerability, as revealed by the 2008 and 2010 riots. This attitude to social protection systems and the poor's ability to use resources changed after the 2010 riots, as the UN and donor agencies concerted their efforts to promote the idea of fiscal space (Cunha et al. 2013; UN Mozambique 2015; interviews INAS, November 2016). ${ }^{45}$

Pushed by these events, the government itself demonstrated an interest in discussing social protection and alternatives in order to mitigate the impact of the food and fuel crises, and the prime minister contacted the ILO and the IMF to discuss the role that social protection could play in this regard (UN Mozambique 2015: 9; confirmed by INAS interviews in 2016). ${ }^{46}$ From 2008 to 2010, only a slight increase in the budget allocated to INAS was recorded, assessed as a percentage of GDP (see Figure 2). The most important increase in the budgetary allocation took place in 2012, precisely following approval of the operational plan for ENSSB I and the emergence of the pilot study leading to the implementation of PARP.

In sum, the riots pushed the poverty crisis to the forefront of political concerns, as they were experienced as an existential threat to the government's political and financial survival. Thus, even though ideas about laziness predominated over other ideas about how to deal with poverty at this time, they were overtaken by foundational ideas concerning 'national unity' organised in and around the continued dominance of the Frelimo party as the legitimate government of the country. ${ }^{47}$ Social protection at this stage became important for the ruling elite, as they could see that

\footnotetext{
${ }^{45}$ During 2011, the IMF produced a series of studies aimed at demonstrating the room that existed in the government's budget for increasing allocations to social protection and their possible implications for poverty reduction (UN Mozambique 2015).

${ }^{46}$ This refers to a quote from an interview with Elsa Alfai, senior advisor to the minister of gender, child and social action, and was reconfirmed during our interview with her on 21 November 2016.

${ }^{47}$ The discourse of laziness at this time should also be seen as an attempt to protect the Guebuza administration from the potential failure related to the implementation of povertyreduction policies. The discourse of laziness collectivised responsibility among the majority of the poor for the continued situation of poverty.
} 
adopting it would help it solve other problems, such as neutralising the fear of urban youth mobs. How, more specifically, can we understand the lure of the PASP in the context of the riots?

\subsection{Big political tool that created a window of opportunities}

A series of visits and exchanges to South Africa, Brazil, etc., organised for INAS by UN agencies, aid partners and key ministry staff from the core ministries and parliament, was considered particularly fruitful in getting work programmes onto the agenda for social protection. As one UN representative suggested, at this point it became clear to the government 'how social protection could be a big political tool'. ${ }^{48}$ In particular, the experience of South Africa, where 'social protection keeps the lid on potential social unrest with 40 percent of the poor outside the economy', was a revelation made during one of the exchange visits after 2010. Social transfers and public works programmes, for all their good intentions pushed by donors, were 'also a big political tool' of social engineering, and Mozambican government officials 'took note'. This changed the perceptions of many and sidelined those who were still against the idea of social protection. ${ }^{49}$ It is in this broader policy context that the World Bank PASP programme emerged, as it was seen as a direct consequence of these experiences, allowing the government to stabilise urban centres by providing much needed jobs for 'the angry young men' (Buur 2015), who were seen to have been driving the urban unrest in 2008 and 2010.

Trying to answer the question of whether the PASP, with its focus on employment generation, stemmed from the World Bank, or rather from political elites concerned about 'laziness', urban unrest and unemployment in Mozambique, is not easy to pin down causally. This is because there seems to have been a perfect 'best fit' between the policy options available (supply from the Bank) and needs (the demands of the government). This 'best fit' made sure that the PASP became a key factor in stabilising a regime under pressure, which the Bank used to speed up the 'reform' of what was considered a 'business as usual' situation. ${ }^{50}$

The PASP is similar to other programmes supported by the Bank in other African countries like Rwanda, Ethiopia and Tanzania, ${ }^{51}$ but it also has 'a reform agenda' that is purely Mozambican. 'We wanted to change business as usual'. ${ }^{2}$ What the Bank was referring to by the phrase 'change business as usual' was the rampant 'patronage' in the country and the need to 'do the work differently based on rules, manuals and systems' (ibid; while a World Bank agenda, it was shared by many bilateral donors, who also felt threated by the Bank's approach). Even though

\footnotetext{
${ }^{48}$ Interview, multilateral aid partner, Maputo November 2016, confirmed by several bilateral aid partners.

${ }^{49}$ Interview, multilateral aid partner (not World Bank), Maputo, November 2016, confirmed by several bilateral aid partners.

50 Interview, World Bank, Maputo, October 2016.

51 Besides South Africa, Mozambican state, parliament and government representatives participated in numerous study tours (see UN Mozambique. 2015: 9)

52 Interview, World Bank, Maputo, December 2016.
} 
attempts to introduce innovations, like updated payment methods and management information systems, have been attempted by the donor and multilateral donor group during both the ENSSB I and II (Hodges et al. 2014), they had been frustrated.

Before the 'PASP there was no formal register of beneficiaries, no information management system, no formal system to ensure access', there was only "faith" we had to trust who had been paid'. ${ }^{53}$ Even through this was an exaggeration, ${ }^{54}$ there was, according to many bilateral donors, also some truth to the assertion. In addition, the Bank also wanted to change who had access to the PASP, for example, by insisting that it mostly be implemented in Zambezia, thus breaking the distributional logic of other state transfers. ${ }^{55}$ Thus, besides using a substantial part of the loan to reach the urban young, the Bank also wanted to reach neglected areas of Mozambique. This 'obviously challenged business as usual', and implementation was slow - actually hardly anything happened with regard to actual distribution (except capacity and organisational building) before the debt crisis set in and donor funding of the state budget diminished. Without change to the status quo there would be limited expenditure and that became a major incentive for the state functionaries. ${ }^{56}$

Since the debt crisis seriously kicked in around 2016, the implementation of a proper register, targeting based not on the discretionary power of permanents, but on whole communities classified as needy, and the payment of beneficiaries by organisations and electronic technology controlled by other institutions than the state in order to minimise transaction costs had all been speeded up significantly according to the Bank and state officials. What had earlier been slow and resisted 'is now possible or easier to agree on; we need to use this opportunity' (ibid.). This was recognised by INAS, which had 'suspended' all other activities temporarily and deployed all its staff to make sure the PASP moved faster, as 'this is the only programme that has funding at the moment, as (financial) aid is suspended' due to political problems. ${ }^{57}$

\section{Conclusion}

This paper has shown that the framework for political settlements that has guided this research can provide key insights into the motivations of the Mozambican government and its aid partners in adopting and implementing social protection in Mozambique. It is also clear that separating ideas like national unity (foundational) from an interest-based political settlement analysis may be less clear-cut, as, at least in Mozambique, they seem to be intertwined in practice. The ruling Frelimo elite could, for example, see the benefits of adapting itself to what were predominantly donor-driven social protection modalities like the PSSB, as this helped it solve other

\footnotetext{
53 Interview, World Bank, November 2016.

${ }^{54}$ Actually, a manual information management system exists for PSSB but it was indeed manual and thereby slow and proven for manipulation (as if electronic systems are not manipulative). Furthermore, a system of ID cards and fingerprinting mark who had been paid was in operation but the scope was limited.

${ }^{55}$ Interview, World Bank, November 2016.

${ }^{56}$ Interviews in INAS during November 2016.

${ }^{57}$ INAS interview, 2016.
} 
problems related to poverty reduction and thereby it became government driven. The same happened later on with the PASP, when the government was challenged by urban riots.

However, it also became clear that the particular ways in which social protection programmes like the PSSB fed into the organisation of power in society were challenged. Both ENSSB I (2010-16) and ENSSB II (2016-24) included attempts to introduce innovations like updated payment methods and management informationsystem capacity-building components that would seriously change the way INAS would operate as the implementing agency; but little progress was made until the crisis that followed the second riots, when the government asked the World Bank to finance and assist it with the PASP. The PASP cut right through the INAS way of running projects, setting up what the Bank initially saw as an alternative parallel system for implementation that, as the political and economic crisis escalated from the end of 2015, was adopted by the government. With the debt crisis, INAS has temporarily committed nearly all its staff to the PASP, and practices related to the identification and registration of beneficiaries, the payment of benefits by third parties, etc., suddenly became possible after years of red tape.

In other words, the Bank's reform drive embedded in the PASP, which was aimed at challenging the PSSB's 'business as usual' habits regarding the inefficient use of resources supporting partisan distribution and patronage logics was adopted when no other sources of funding were available, due to the suspension of financial aid in the aftermath of the crisis surrounding secret loan-taking. It is therefore fair to say that the political settlement has shaped the commitment to and design of social protection in Mozambique in important, non-linear ways. Social protection was initially not a home-grown, necessary sector to focus on, but as the INAS bureaucracy and other relevant government institutions became part of an international policy alliance involving training, exchange visits etc., it was able to insert itself exactly when a window of opportunity emerged in the slipstream of the first riots and the poverty-reduction crisis that threatened the financing of the state in important ways, given that reaching the poor was a donor imperative. 


\section{References}

Barnes, H. Castelo, V., Castigo, F., Cruz, A., Mpike, M., Noble, M. and Writ, G. (2016). 'Tax-benefit microsimulation modelling in Mozambique: A feasibility study'. WIDER Working Paper, No. 2016/27,

Bertelsen, B. (2014). 'Effervescence and ephemerality: Popular urban uprisings in Mozambique'. Ethnos 2014: 1-28.

Boletim da República (2011). Decreto N ${ }^{\circ}$. 52/2011, 12 October. Decree that created the basic social protection programmes.

Bundy, D., Burbano, C., Grosh, M., Gelli, A., Jukes, M. and Drake, L. (2009). Rethinking School Feeding: Social Safety Nets, Child Development, and the Education Sector. Washington, DC: World Bank.

Buur, L. and Suarte Baloi, O. (2009). The Mozambican PRSP Initiative: Moorings, Usage and Future. Danish Institute for International Studies, Copenhagen Working Paper: Elites, Production and Poverty Subseries, 2009(35): 1-44.

Buur, L. (2015). Sovereignty, riots, and social contestation: Excess and domestication. Conflict and Society: Advances in Research, 1(1): 165-81.

Cunha, N., Pellerano, L., Mueller, J., Lledo, V., Xiao, Y. and Gitton, P. (2013). Toward a Mozambican Social Protection Floor: Consolidating a Comprehensive Social Protection System in Mozambique - Analysis of Policy Alternatives and Costs. Geneva: ILO-Social Security Department.

de Brito, L. (2016). 'Instituicoes políticas e unidade nacional'. Desafios para Moçambique 2016. Maputo: IESE. Pp. 23-31.

Forquilha, S. and Orre, A. (2012). 'Uma iniciativa condenada ao sucesso'. In B. Weimer (ed.), Moçambique, descentralizar o centralismo: economia política, recursos e resultados. Maputo: IESE. Pp. 168-96.

Francisco, A. (2013). “Acção social productiva” em Moçambique: Uma falsa solução para um problema real'. In Desafios Para Moçambique 2013. Maputo: Instituto de Estudos Sociais e Económicos (IESE). Pp. 357-93.

Francisco, A., Ali, R. and Ibraimo, Y. (2011). 'Protecção social financeira e demográfica: Desafios para uma segurança humana digna em Moçambique'. In Desafios Para Moçambique 2011. Maputo: Instituto de Estudos Sociais e Económicos (IESE). Pp. 283-331.

Francisco, A. and Sugahara, G. (2014). 'Para além do espaco fiscal: a proteccao social no context da transicao demografica Mozambicana'. In Desafios Para Mozambique 2014. Maputo: Instituto de Estudos Sociais e Economicos (IESE). Pp. 281-312. 
Francisco, A. and Sugahara, G. (2015). 'Porgue Moçambique ainda não possui uma pensão universI para idosos?' In Desafios Para Mozambique 2015. Maputo: Instituto de Estudos Sociais e Economicos (IESE). Pp. 349-82.

Frelimo (1978). Central Committee Report to the Third Congress of FRELIMO (1978). London: Mozambique, Angola and Guine Information Centre, 1978.

Frynas, G., Wood, G. and Hinks, T. (2017). 'The resource curse without natural resource: Expectations of resource booms and their impact'. African Affairs, 116(463: 233-260.

George, A. L. and Bennett, A. (2004). Case Studies and Theory Development in the Social Sciences. Cambridge, MA and London: MIT Press.

Hall, M. and Young, T. (1997). Confronting Leviathan: Mozambique since Independence. Athens, $\mathrm{OH}$ : Ohio University Press.

Hanlon, J. (1991). Mozambique: Who Calls the Shots? London: James Currey.

Hodges, A. and Pellerano, L. (2010). Development of Social Protection: Strategic Review for UNICEF Mozambique. Final Report. Oxford: Oxford Policy Management.

Hodges, A., Pellerano, L., Guimarães, L., Matos, N. and Selvester, K. (2014). Avaliação e Revisão da Estratégia Nacional de Segurança Social Básica. Revisão da ENSSB 2010-2014. Oxford: Oxford Policy Management, 23 November.

Hodges, T. and Tibana, R. (2005). A Economia Política do Orçamento em Moçambique. Principia: Publicações Universitárias e Científicas.

ILO and IMF (2012). Toward Effective and Fiscally Sustainable Social Protection Floors. Preliminary Draft 10 May 2012. Preliminary report prepared for the meeting of the G20 labour and employment ministers in Guadalajara (Mexico), 17-18 May 2012, on the state of ILO-IMF collaboration in exploring the fiscal feasibility of national social protection floors in selected countries. Geneva: ILO; Washington, DC: IMF.

INAS (2012). Relatório Anual 2012. Maputo: National Institute of Social Action

INAS (2013). Relatório Anual 2013. Maputo: National Institute of Social Action

INAS (2014). Relatório Anual 2014. Maputo: National Institute of Social Action

INAS (2015). Relatório Anual 2015. Maputo: National Institute of Social Action

INAS (2016). Balanço do PES: Terceiro Trimestre 2016. Maputo: National Institute of Social Action

INE (2007). III Recenseamento Geral da População e Habitação. Maputo: National Institute for Statistics 
INE (2009). Mozambique: Final Report of the Multiple Indicator Cluster Survey, 2008. Maputo: National Statistics Institute. Directorate of Demographic, Life and Social Statistics.

Khan, M. (2010). Political Settlements and the Governance of Growth-Enhancing Institutions. Research Paper Series on Governance for Growth. London: School of Oriental and African Studies, University of London.

Lavers, T. and Hickey, S. (2015). 'Investigating the political economy of social protection expansion in Africa: At the intersection of transnational ideas and domestic politics'. ESID Working Paper 47. Manchester: Effective States and Inclusive Development Research Centre, The University of Manchester.

Lavers, T. and Hickey, S. (2016). 'Conceptualising the politics of social protection expansion in low-income countries: The intersection of transnational ideas and domestic politics'. International Journal of Social Welfare, 25: 388-398.

Lavers, T. (2016). 'Understanding elite commitment to social protection: Rwanda's Vision 2020 Umurenge Programme'. UNU-WIDER Working Paper 2016/093, August. Helsinki: United Nations University World Institute for Development Economics Research.

Macuane, J. J., Buur, L. and Monjane, C. M. (2017). 'Power, conflict and natural resources: The Mozambican crisis revisited'. African Affairs, : 1-24.

Macuane, J. J. (2012). 'Economic and political liberalization, dependency and elite formation in contemporary Mozambique'. DIIS Working Paper 2012(09): 1-42. Copenhagen: Danish Institute for International Studies.

Marques, J. S. (2012). Mozambique Social Protection Assessment: Review of Social Assistance Programs and Social Protection Expenditures. Africa Social Safety Net and Social Protection Assessment Series. Washington, DC: Social Protection Advisory Service, World Bank.

Massingarela, C. and Nhate, V. (2006). The Politics of What Works: A Case Study of Food Subsidies and the Bolsa-Escola in Mozambique. Background Paper for the Chronic Poverty Report 2008-09. Chronic Poverty Research Centre.

Mausse, M. and Cunha, N. (2011). 'Mozambique: Setting up a social protection floor'. Chapter 14 in Sharing Innovative Experiences, Volume 18: Successful Social Protection Floor Experiences. New York: UNDP, Special Unite for South-South Cooperation.

MEF-DEFS (2016). 'Poverty and well-being in Mozambique: Fourth National Poverty Assessment (IOF 2014/15)'. October 2016. Maputo: Ministry of Economics and Finance, Directorate of Economic and Financial Studies. Available online: https://www.wider.unu.edu/sites/default/files/Abstract Executive Summary EN 4Ev 
al.pdf (accessed 5 July 2018).

Mozambique News Bulletin (2016). 'Poverty survey supplement'. No. 344, 31 October. Edited by J. Hanlon. Available online: http://www.open.ac.uk/technology/mozambique/sites/www.open.ac.uk.technology.mo zambique/files/files/Poverty survey supplement to Mozambique 344310ct2016(1).pdf (accessed 5 July 2018).

Mozambique News Bulletin (2010). 'Economic paradox 2'. No 170, 29 September. Edited by J. Hanlon. Available online: http://www.open.ac.uk/technology/mozambique/sites/www.open.ac.uk.technology.mo zambique/files/pics/d135470.pdf (accessed 5 July 2018).

Mozambique News Bulletin (2008). 'Guebeza: Poverty has declined'. No. 135, 3 September 3. Edited by J. Hanlon. Available online: http://www.open.ac.uk/technology/mozambique/sites/www.open.ac.uk.technology.mo zambique/files/pics/d100054.pdf (accessed 5 July 2018).

Mozambique News Bulletin (2007). 'Are peasants lazy? The debate begins'.. No. 115, 20 April. Edited by J. Hanlon. Available to download: http://www.open.ac.uk/technology/mozambique/sites/www.open.ac.uk.technology.mo zambique/files/pics/d75975.doc (accessed 5 July 2018).

MPF (2004). Segunda Avaliação da Pobreza em Moçambique. Ministry of Planning and Finance, International Food Policy Research Institute (IFPRI) and Purdue University. Maputo: Ministry of Planning and Finance.

ORGUT (2016). Constatacoes da Realidade em Mozambique. Relatório Final 20112015. ORGUT consulting with CMI and COWI. Maputo: Swedish Embassy.

Renzio, P. de, and Hanlon, J. (2008). 'Mozambique: Contested sovereignty? The dilemmas of aid dependency'. In L. Whitfield (ed.), The Politics of Aid: African Strategies for Dealing with Donors. Oxford: Oxford University Press. Pp. 246-270.

República de Moçambique (2010). Estratégia Nacional de Segurança Social Básica 2010-2014. Maputo.

República de Moçambique (2016). Estratégia Nacional de Segurança Social Básica 2016-2024. Maputo.

Seekings, J. and Nattrass, N. (2005). Class, Race, and Inequality in South Africa. London: Yale University Press.

Soares, F. V., Hirata, G. and Ribas, R. P. (2009). Evaluation of the Programa Subsidio de Alimentos in Mozambique: An Analysis of the Baseline Survey. Brasilia: International Policy Centre for Inclusive Growth. 
Sugahara, G. and Francisco, A. (2012). 'Idosos em Mozambique: Romper a Conspiração do Silencio'. In Desafios Para Moçambique 2012. Maputo: Instituto de Estudos Sociais e Económicos (IESE). Pp. 295-331.

Tvedten, I., Paulo, M. and Rosário, C. (2006). “Opitanha”: Social Relations of Rural Poverty in Northern Mozambique. CMI Report R2006:16. Bergen, Norway: Chr. Michelsen Institute.

UN Mozambique (2015). Capitalizing on UN Experience: The Development of a Social Protection Floor in Mozambique. Mozambique.

UN Mozambique (2011). Child Poverty and Disparities in Mozambique 2010. Maputo: UNICEF.

Walton, J. and Sneddon, D. (2011). Free Markets and Food Riots: The Politics of Global Adjustment. London: Blackwell.

Waterhouse, R. and Lauriciano, G. (2009). The Political and Institutional Context for Social Protection in Mozambique - A Brief Overview. Maputo: IESE.

Weimer, B., Macuane, J. J. and Buur, L. (2012). 'A economia do political settlement em Moçambique: contexto e implicações da descentralização', in B. Weimer (ed.), Moçambique, descentralizar o centralismo: economia política, recursos e resultados, pp. 31-Maputo: IESE.

WFP and INAS (2012). Productive Safety Net: Pilot Project. Evaluation Report. Mozambique.

Whitfield, L., Therkildsen, O. Buur, L. and Kjær, A. M. (2015). The Politics of African Industrial Policy: A Comparative Perspective. New York: Cambridge University Press.

World Bank (2013). Social Expenditure Review, International Development Association Project Appraisal Document on a Proposed Credit. Report No: 73608MZ. Washington, DC: World Bank.

World Bank (2016). Accelerating Poverty Reduction in Mozambique: Challenges and Opportunities. Available online: http://documents.worldbank.org/curated/en/383501481706241435/pdf/110868-

ENGLISH-PUBLIC-Final-Report-for-Publication-English.pdf (accessed 5 July 2018). 


\section{Material consulted}

Bond, P. (2012). African Reactions to the Global Economic Crisis. In (ed.) U. Schuerkens, Socio-economic Outcomes of the Global crisis: Theoretical Discussion and Empirical Case Studies. London: Routledge. Pp. 222-238.

Castel-Branco, C. N., Massingue, N. and Muianga, C. (2015). 'Padrões de investimento privado e tendências especulativas na economia moçambicana'. Boletim Ideias 75, Instituto de Estudos Sociais e Económicos (IESE), Maputo, 23 June.

Dava, P. O., Chigora, P., Chibanda, T. W. and Sillahet, R. (2013). 'An analysis of the effects of civil war and prospects for development in Mozambique: The case of Frelimo-Renamo in Chokwe district'. International Journal of Humanities and Social Science Invention 2(6): 66-75.

Falange, S. and Pellerano, L. (2016). 'Social protection reform in Mozambique and the new basic social security strategy'. International Policy Center for Inclusive Growth. November.

Fozzard, A. (2002). 'How, when and why does poverty get budget priority: Poverty reduction strategy and public expenditure in Mozambique'. Overseas Development Institute, Working Paper 167. London.

Gliszcynski, von, M. (2015). Cash Transfers and Basic Social Protection: Towards a Development Revolution. Basingstoke: Palgrave.

Hanlon, J. and Smart, T. (2008). Há Mais Bicicletas: Mas Há Desenvolvimento? Maputo: Kapicua Livros e Multimédia.

ILO (2014). Budget Brief 2014: Social Welfare Sector in Mozambique. Maputo: ILO.

ILO (2011). Levantamento do Quadro Legal-Institucional Local (Distritos e Municípios) em vista do Programa Nacional de Acção Social Produtiva. Prepared by LEXTERRA..

INAS (2010). Relatório Anual 2010. Maputo: National Institute of Social Action.

INAS (2011). Relatório Anual 2011. Maputo: National Institute of Social Action.

INAS (2015b). Informe Orcamental 2015: Accao Social. Funded by UNICEF, ILO, Forum de Monitoria do orcamento, PSC PS and ROSA. Maputo.

Low, J. W., J. Garret and V. Ginja (1999). 'Can cash transfer programs work in resource-poor countries? The experience of Mozambique'. FCND Discussion Paper 74. October. Washington, DC: IFPRI. 
Ortiz, I Cummins, M. and Karunanethy, K. (2015). 'Fiscal space for social protection. Options to expand social investments in 187 countries'. ESS Working Paper 48. Geneva: International Labour Office.

Scarlato, M. and d'Agostino, G. (2016). 'The political economy of cash transfers: A comparative analysis of Latin American and Sub-Saharan African experiences'. DIE Discussion Paper 6/2016. Bonn: Deutches Institute für Entwicklungspolitik. .

Selvester, K., Fidalgo, L. and Tambo, N. (2012). Transforming Cash Transfers:Beneficiary and Community Perspectives of the Basic Social Subsidy Programme in Mozambique. London: Overseas Development Institute.

Soares, F. V. and Teixeira, C. (2010). Impact Evaluation of the Expansion of the Food Subsidy Programme in Mozambique. Research Brief 17, December. Brasilia: International Policy Centre for Inclusive Growth.

Soares, F. V., Hirata, G. I. and Ribas, R. P. (2010). 'The Programa Subsídio de Alimentos in Mozambique: Baseline evaluation'. Research Brief 14. Brasilia: International Policy Centre for Inclusive Growth.

UN Mozambique (2006). Childhood Poverty in Mozambique: A Situation and Trends Analysis.: Maputo: UNICEF.

Waterhouse, R. (2009). Vulnerability in Mozambique: Patterns, Trends and Responses. Conference Paper presented at the IESE conference on 'Poverty Dynamics and Patterns of Accumulation in Mozambique'. Maputo, 22-23 April 2009. 


\section{esid}

\section{The Effective States and Inclusive Development Research Centre}

The Effective States and Inclusive Development Research Centre (ESID) aims to improve the use of governance research evidence in decision-making. Our key focus is on the role of state effectiveness and elite commitment in achieving inclusive development and social justice.

ESID is a partnership of highly reputed research and policy institutes based in Africa, Asia, Europe and North America. The lead institution is The University of Manchester.

The other institutional partners are:

- $\quad$ BRAC Institute of Governance and Development Institute, BRAC University, Dhaka

- Institute for Economic Growth, Delhi

- Department for Political and Administrative Studies, University of Malawi, Zomba

- $\quad$ Center for Democratic Development, Accra

- $\quad$ Centre for International Development, Harvard University, Boston

In addition to its institutional partners, ESID has established a network of leading research collaborators and policy/uptake experts. 